\title{
An Analysis of That Deadman Dance from the Perspective of Eco-criticism
}

\author{
Weiwei Wang ${ }^{1} \&$ Hongwei $\mathrm{Li}^{2}$ \\ ${ }^{1}$ Qinhuangdao Branch of Northeast Petroleum University, Qinhuangdao, China \\ ${ }^{2}$ One-paper Training Center, Taizhou, Zhejiang, China \\ Correspondence: Weiwei Wang, Department of Basic Courses, Qinhuangdao Branch of Northeast Petroleum \\ University, 550, West Hebei Street, Haigang District, Qinhuangdao, Hebei 066004, China. E-mail: \\ steviv2003@126.com
}

Received: January 27, 2015 Accepted: February 10, 2015 Online Published: February 25, 2015

doi:10.5539/ells.v5n1p131 URL: http://dx.doi.org/10.5539/ells.v5n1p131

\begin{abstract}
Kim Scott is an extraordinary Australian writer. More and more Australians pay their attention to Kim Scott's works, studying Kim Scott's novels from the perspective of post-modernism. The author of this paper intends to study Kim Scott's novel of That Deadman Dance and explores his ecological consciousness in it as his novel describes the relation of humans and nature, the white and the aborigines, and man and self. Ecology is an interdisciplinary subject that is concerning life and environment, human and nature, human and society as well as spirit and material. Eco-criticism extends ecology to explore and criticize ecological ideology reflected in literary works. This paper is based on the U.S. eco-scholar Cheryll Glotfelty's theory of eco-criticism and employs the three divisions of ecology put forward by Professor Shuyuan Lu.

Through the analysis of the ecological points of the white and the aborigines, the interpretation of the white social ecology and the aboriginal social ecology and the description of the white's and the aborigines' spiritual world, the paper reveals how man and nature can co-exist in harmony, the advantages of the aboriginal social ecology and spiritual ecology to solve the crisis. The novel expresses the writer's thoughts over ecological crisis and he thinks that respecting nature and keeping natural, social and spiritual harmony is the right way to get out of the crisis.
\end{abstract}

Keywords: eco-criticism, natural ecology, social ecology, spiritual ecology, That Dead Man Dance

\section{Introduction to Ecological Literary Criticism}

Eco-criticism, also called "studies of Literature and Environment", appeared in the western and America in 1970s and formed in America in 1990s. It stood out in the literary criticisms at the end of 20th century. It is defined as "the study of the relationship between literature and the physical environment" (Glotfelty, 1996, xviii) by the founder of eco-criticism Cheryll Glotfelty in her work The Eco-criticism Reader in 1996. It focuses on the relationship between human beings and the natural environment. Eco-criticism brings the ecological perspective into the study of literature against the background that the ecological environment becomes worse and worse and the ecological crisis is more and more serious. Eco-criticism studies literary from the perspective of ecology and affects the formation of the policy that is good for the balance between human and nature. It can dig out the ecological consciousness embodied in the literature. At the same time it criticizes the culture which is harmful to the balance of nature and arouse people's ecological consciousness to protect the nature. Therefore, people have positive ecological behaviors which are important to achieve harmony among nature, society and themselves.

At the early stage of the theory, critics and literary works just focus on the relationship between man and nature. They pay much attention to environmental protection and the study of nature writing in literary field. Eco-criticism studies how nature and environment are described in literature. It criticizes human being's excessive exploitation on nature and suggests harmonious relationship between man and nature. The conflicts between man and nature lead to natural crisis, but it's not the only crisis that the industrialization arouses, the conflicts among people lead to social crisis and the conflicts of self leads to spiritual crisis. At present the core of ecological crisis is the relationship between man and nature. To solve the ecological crisis not only depends on the solution of natural ecological crisis, but also on the solution of the social ecological crisis and spiritual 
ecological crisis. So social ecology and spiritual ecology are also the objects that eco-criticism should study.

Actually, ecological crisis is a social problem. Max notes that the basic source of ecological crisis is social causes. The rise of ecological crisis is that man has not really understood the relationship between man and nature. In a society that materialism is put in priority, it intensifies people's desire for wealth and resources and leads people to exploit nature. It leads to a social system that is harmful to the nature. A good literary work can cause people to rethink social system and assist government in correcting unreasonable behaviors.

Ecological crisis not only exists in nature and society, but also in people's spirits. The imbalance in society and nature is also spreading to man's spiritual world. Man's spiritual crisis will lead to more serious results that man would destroy themselves in spirits and then the world. Facing so many ecological crises, people begin to pay attention to their spiritual ecology. According to Professor Shuyuan Lu, ecological crisis roots from human's spiritual crisis and cultural crisis. It is human's values and aims that influence their attitude to nature. Eco-criticism should not only analyze nature in literature, but should probe into the root of ecological crisis from the perspectives of spirit and society. Therefore the theories of spiritual ecology and social ecology come into being.

From the above we can see that the eco-criticism has expanded from the natural field to the social and spiritual fields. In fact, many literary works also reveal the crises growing in both ecosphere and spiritual sphere. Australian writer Kim Scott is such a man whose novels describe the natural, social and spiritual crises in Australia and gives his own solution to the crises from the aspect of eco-criticism.

\section{Kim Scott and His That Deadman Dance}

Scott was born in Perth in 1957 and grows up near Albany, WA. After studying literary theory and being an English schoolteacher, he becomes an academic in indigenous health and culture. Scott, who is from south-west Western Australia and has mixed Noongar and English heritage, is deeply concerned with the life of the Aboriginal people and their relationship with the white. Also, Scott is the first indigenous writer to win the Miles Franklin Award for Benang, which has since been published in translation in France and the Netherlands. And his third novel That Deadman Dance brings the honor to him again. He considers it his responsibility to depict the life and destiny of the Indigenous people as he says: "I'd like to think that writing fictions is sometimes a way to explore, to rethink and possibly to retrieve or create something from between and behind the lines on the page. As such it can help the revitalization and regeneration of an Indigenous heritage..." (Scott, 2007, p. 123)

That Deadman Dance tells a story about the first contact between the Aboriginal (Noongar) people, British colonists and American whalers. The protagonist Bobby makes great efforts to make a connection between the Aboriginal people and the white who come to the south coast of Western Australia, but he fails in the end. He acts as a bridge between the two sides at first and also he is welcomed by the white family who need his help to seek more land and fortune. But as the whites get familiar with the place and the people, they impose strict regulations on the local people and want to control everything there. Conflicts arise inevitably and a peaceful coexistence is hard to achieve between the Indigenous people and the colonists as the latter deny the former's humanity and identity, taking them as an interior existence.

\section{Ecological Analysis in the Novel}

\subsection{Natural Ecology in the Novel}

\subsubsection{The White's Exploitation on the Nature}

Dr.Cross is a white and venerable man who leads the First Contact settlement. He has a great desire for land where he could make a new life for his family. With the help of the natives, he really gets a lot of land. The natives enjoy whatever the land comes out while Cross wants to set up a farm on it for more profit. He thinks he is the master of the land, but he does not have the ability and the labor. Every day he will go to the land he owns and images that crops growing on it, but that's just in his imagination and his health gets worse and worse. He can do nothing but sell it out and send the money back to his family. That's the only thing he enjoys from the land and his dream doesn't come true in the end. Obviously the relationship between Cross and the land is not equal and it's a good example of the white's exploitation on the nature. Cross can not treat the land the same as the natives do. He considers the land as a kind of tool which can bring him economic benefit. Once he fails to control the land he becomes depressed. It's really a tragedy of anthropocentrism which puts man above the nature.

Since ancient times, mankind always has a kind of continuous strong attachment to land because it is the basis of mankind and their livelihood. The relationship between land and Cross is comparative. The original image of land is rude, stubborn and uncooperative, which stubbornly refuses people's request. It is difficult for Cross to 
reach a tacit understanding with the land and he is doomed to be a tragic character in the end. In people's eyes, the land is not the basis for survival, but the source of their misery and suffering. In this case, the conflicts between man and land arise which leads to the final integration between man and nature.

Geordie Chaine is another tragic character in the novel. All of his family members come to Australia. He is ambitious of things to do. Driven by profits, he is eager to find land. When he makes an expedition to follow the rivers to the mountains, several of the natives are quite experienced guides who have helped Cross. But Chaine thinks he is the master of the nature, he would rather trust himself than the natives. But as last, the guides help him out when he gets lost. Chaine is too confident. He thinks he can control the nature at his will so the relationship between him and nature is confronted. He can not enjoy himself in the nature but be punished by nature.

Killing whale is always in his list of things he needs to do. Although he makes some progress in whaling, the nature punishes him by an accident. When Skelly, Tar, Killam and Chaine have their heads together over one of the whaleboats, the two of Chaine's children are trapped in the soft sand. The daughter is saved by Bobby but the son never returns. It is a dead hit for Chaine. This made him rethink the relationship between nature and himself.

\subsubsection{The Aborigine's Equal Thoughts to Nature}

Bobby, the protagonist in the novel, loves nature very much. We first meet Bobby at the Part I of the novel. He just returned from a sail with the whites. Exploring the sea is his favorite because he can communicate with the nature closely. The following passage describes how happy he is when he is on the ship.

Drenched with spray, Bobby Wabalanginy stood at the bow with a rope tied tightly around his waist. He bent his knees, swayed from the hips in an attempt to maintain his poise as the ship leapt and plunged. A lunging wave swept him across the deck with nothing to cling to and only the rope to save him. Laughing in fear and excitement, he got to his feet and, hand by hand along the rope, thrust his way against the elements back to where he'd begun. (Scott, 2011, p. 9)

The writer Kim Scott seems to tell us Bobby is a representative of animism. He mainly refers to three kinds of things that can prove animism more useful than anthropocentrism to solve the relationship between human being and nature. In Bobby's eyes the sea is not lifeless and emotionless. Bobby can communicate with it just like with a human being. Bobby knows people do harm to the sea when he sees a lay of whale bones on the beach. When he can't see the spout of the whales he knows the sea will not let the whales come back again. The sea is safeguarding its daughters and sons. This kind of communication between human being and nature is equal. People will not exploit the nature at large. They just get what is the necessary.

In the novel, Kim Scott also describes how Bobby deals with the mountain, the land and the forest and how he benefits from the nature. Owning to constantly communicating with the mountain, Bobby can easily get in and out of the mountains. When the white are short of water or food, Bobby can find some for them effortlessly.

From this novel, we can see the aborigines' opinions on nature are completely different from the white. Their points may have positive effects on the crisis we face today. Though it is impossible for us to return to the original society, we also can apply their points to improve the relationship between nature and man. They treat nature equally. Nature is just a source for them to get their necessary food to sustain their lives instead of overcharging it. In the white's eyes it is not equal between man and nature and the nature is just man's property which can be made use of at their will. Here we can see the white always look themselves as the center of the world.

Aborigines also would not collect more things than they need to make their lives better. The white can find a balance between their desire and the nature. In the novel, the whalers kill whales for whale oil to make money. The white's desire is unlimited but the whale is limited in that area, which leads to the whale's dying-out and the Aborigines' losing an important food source. This is a good example to explain why men were trapped in the ecological crisis.

In fact nature and humans can be harmonious with each other. They can both be co-existent and interdependent on each other. Kim Scott seems to suggest that human beings can live in harmony with nature. If human beings make good use of natural resources, they can easily get it when they really need it. On the contrary, if human beings exploit nature to an undue extent, nature can take its revenge. Harmony with nature instead of egotistical exploitation of Nature may be their right choice.

\subsection{Social Ecology in the Novel}

Besides natural ecology, society is also an ecological system which studies the relationship between human, 
social environment and social structure as the present ecological problems are rooted in deep-seated social problems, particularly in hierarchical social systems. Therefore, the way that human being deal with each other as social beings is crucial to solve the ecological crisis. Human beings need a harmonious social ecology to keep their physical and mental health.

\subsubsection{The White's Corrupt in Social Ecology}

With the rising of bourgeois, they are greedy for more resources from the nature. When they come to Australia, it's their first object to take control of the resources there, and the relationship among the white in Australia also has a great influence on the social ecology. When the whites cooperate in colony, they can change the local ecology faster and have more need for raw material. In some way the cooperation among the white intensify the colonist's loot on the nature. Besides the cooperation, competition is also intense among the white. Mr. Chaine comes to Australia with plenty of capital, senior to the retired soldiers and the released prisoners. He could get more land and other resources in Australia. But he still has to turn to them for help because he is a new comer there and the latter have to work for the bourgeois and save money to buy a little land to realize their colonial dream. The competition among the all kinds of colonists is obvious.

Although the relationship among the white has a deep effect on the local ecology, the more effective factor is the society political and economical system. According to Shuyuan, Lu, ecology can be divided into three parts. They are natural ecology which researches on the natural world, social ecology which researches on the political activities and economical activities and spiritual ecology which researches on man's spiritual activities. (Lu, 2000, p. 146) In fact social ecology researches on the relationship among people. It can greatly affect man's points on nature and their activities toward the nature. When the whites first came to Australia, they not only brought their family and dreams but also social system and social ecology. So when the white landed on Australia, they built houses, farms and set up cities according to their home country and they also required the Aborigines obey their social customs.

\subsubsection{The Aborigine's Advantage in Social Ecology}

It seems that Kim Scott really appreciates the aboriginal harmonious relationship. He argues that the harmonious relationship originates from the special aboriginal economic, cultural and religious system. The Aborigines rely on collecting and hunting to make a living and share the food with no concept of property. In the novel, Kim Scott describes the plot of the Aborigines' stealing sheep and other food from the white's farm. They get together to hunt for food without knowing the sheep they were hunting for is a kind of property of the white. The aboriginal special culture also contributes to their harmonious relationship. Religious belief is always the bond among Aborigines. Most of them believe animism that objects are animate .They treat them as if they were animate and equal to the human beings. It can be an important reason for the Aborigines to form harmonious relationship.

Harmony is the main subject in Kim Scott's novel. Maybe Kim Scott thinks language is an important way to enhance the communication between the white and Aborigines. In the novel, Dr.Cross teaches Bobby English. And Bobby also likes to speak English. Language helps much in the improvement of the relationship between the white and Aborigines. Using the common language gives Bobby a sense of family when he stays with Dr. Cross. "Bobby, a child-stranger at Cygnet River, saw people looking at him from a distance and caught smiles intended for Dr. Cross. Sometimes there was handshaking. Bobby kept at his lessons and stayed in a hut, just as if he was Dr. Cross's own family." (Scott, 2011, p. 26) Mastering a foreign language is a good way to remove the misunderstanding between two peoples. Bobby and Dr Cross's relation is a good example. Bobby helps him find land to grow crops and helps Dr. Cross out when Dr. Cross is surrounded by the hostile aborigines. Dr. Cross also learns some aboriginal languages, which makes the Aborigines think Dr. Cross is a good kind man so they have a different opinion on the white.

While language can promote understanding between two peoples, identifying with other people's customs is also a very important way to form a good relationship. The Aborigines think that the person who identifies with their customs will be their friend. In early days when the white come to Australia, some white people also identify with the marriage system of the Aborigines. In the novel, Bobby explains their marriage system. A man might bring food to the family of even a baby girl who will be his wife when she grows up; he look after them well and good. And when she's old enough, she goes with him. The family wants a good strong man. Jak Tar, the pilot, who is American, falls in love with an aboriginal woman. He obeys the aboriginal marriage custom. Jak had made many visits with Bobby to talk with the family of Binyan according to the local customs and finally Jak was admitted by the family of Binyan. On the contrary, if people ignore another people's customs, it will bring conflicts between them. The white consider the local customs uncivilized and they force the Aborigines to put on 
clothes to enter their town. It is considered disrespected and unaccepted by the Aborigines and they resist the clothes that the white offer. And although Bobby is a good friend of Chaine he would not marry Chaine's daughter because Bobby is an inferior Aborigine in the eyes of the white who "put their own people over the top of all of us (the Aborigines) who've always been here."(Scott, 2011, p. 362) According to Anne Brewster, "There is a fundamental disjunction between the ways in which the settlers generally relate to the Noongar and the ways in which the Noongar react to the presence of the settlers." (Brewster, 2011, p. 61)

\subsection{Spiritual Ecology in the Novel}

Kim Scott also explores on the people's misplaced spiritual ecology. Ecological studies have shown that a man is not only a natural existence or social existence, but also a spiritual existence. If the natural ecology is reflected in the relationship between people and nature and social ecology deals with relationship between people, the spiritual ecology is reflected in man's relationship with himself. They are in the loss of self-identity and their spiritual ecology is dislocated.

\subsubsection{The Spiritual Problem of the White}

The story in the novel happened in 19th century when capitalism developed fast. Deeply influenced by the thought that the more property you gain, the happier you are, Dr. Cross comes to King George Town to realize his dream in spite of his poor health and old age. Dr. Cross uses his wife's inheritance to buy a lot of land to set up his own farms, but his plan fails and he is trapped in dilemma and he is defeated by his own spirits.

As soon as Geordie Chaine lands on Australia, his mind is taken up by all kinds of expectations and he is eager for success. The measure of success is if he can succeed in getting much money. At the beginning of the story, Chaine has a long list of things that he must finish, but all of his expectations end up in failure. His small farm is troubled constantly by the Aborigines and the sheep in his pasture are stolen by the Aborigines because they have no concept of private ownership. And his whale ship could not compete with the American ship. All the failures put him in low spirits as they all become the slaves of materialism and capitalism, and they are doomed to be tragic characters in spirit.

\subsubsection{Some Enlightenment from the Aborigines' Spiritual Ecology}

When we talk about spiritual ecology we have to refer to people's value orientation. Different value orientations will result in different spiritual lives. The aborigines' value orientation in Kim Scott's novel seems have superiority to the white. The white put the money in the first place while the Aborigines pay much attention to the spirit. Material means a necessity to their life instead of a kind of fortune. What the Aborigines value is something spiritual. Though they have low desire for material life, they enjoy high quality of spiritual life. The protagonist, Bobby, is such a man. He can enjoy his life in the hard time. "Bobby started playing. He did his shipboard things floating in the water and the wave moving along them;' and Bobby took little steps side to side, like on the deck of a ship. The men lay down, and Bobby walked across their moving bodies, like the boat in the harbor going from ship to shore. Walking on the waves, see? And then he was staggering side to side and mined lifting a bottle to his lips: that dance the sailors do."(Scott, 2011, pp. 58-59)

It seems that the spiritual life is more important than the material life. Rich spiritual life can make the Aborigines forget the hardship. They use this kind of form to strengthen their contact and keep their special culture going on. Making friends also is Bobby's way to polish his spirit. He makes friends with Dr. Cross who teaches him English and treats Bobby as his family member.

It seems that happiness from the spirits is far more important than that from the material the white value most. Professor Shuyuan $\mathrm{Lu}$ thinks that healing the damaged human spirit is as important as recovering the damaged nature. He claims that besides natural ecology there should be spiritual ecology. Professor Lu's definition of spiritual ecology is that a discipline that studies the relationship between subjects as spiritual existence (mainly human beings) and the environments in which they live including natural environment, social environment and cultural environment. Spiritual ecology involves not only the healthy growth of subjects, but also the balance, stability and development of an ecosystem under the coordination of spiritual variables. (Lu, 2006, p. 63)People gradually realize that natural ecological crisis must be followed by the crisis of human relationship because man's conquest on nature leads to man's conquest on human beings. It causes man's alienation from nature and society. At the same time, this kind of alienation causes man's spiritual crisis. By describing the white's and the aboriginal spiritual crisis, Kim Scott gives his answer to how to deal with man's spiritual crisis.

\section{Conclusion}

Kim Scott is a writer of great importance in Australia literature. He shows his genius in his first novel True Country and gains his place through his novel Benang. With his latest novel That Deaman Dance published, Kim 
Scott becomes more and more popular in Australia and even around the world. The reason why he is paid much attention is that he focuses his energy on the problems that are cared about by most of people in the world and they are given solutions and special opinions by Kim Scott.

Kim Scott cares about the nature ecology. With the fast development of industry, people get economic and social prosperity at the expense of the natural environment which has made the survival of mankind into a deep crisis. Inevitably, the crisis also extends to Aborigines' community of Australia. Kim Scott describes the start of the crisis in his novel which happened at the eve of Britain industrialization. As we all know Australia is a primitive land before the Europeans came to the land, but its ecology system became worse and worse because of the Europeans' destruction. Not only Kim Scott shows us people destructive actions, but also he gives us some hints to solve the problem, that is, the achievement of the harmony between human being and nature is the best way to solve the crisis.

Kim Scott also cares about the social ecology. It is evident that a harmonious society is essential to a harmonious natural ecology. Many critics and historians only focus on the intense relation between the Aborigines and the white in Australia, while Kim Scott shows us some positive and cooperative relation between the two sides, especially the relation between Bobby and the white. Kim Scott suggests that different peoples learning each other's language and culture is the premise of peace. Therefore, Bobby learns English from Dr. Cross and Mr. Chaine and Dr. Cross tries to learn the aboriginal languages, which makes is possible for them to become friends.

People's spiritual ecology is also what he concerns. People's performance results in today's ecological crisis. How to improve people's performance is the key to solve the crisis. After comparing the Aborigines' spiritual ecology with the white's, he thinks that the Aborigines' spiritual ecology is superior to the white's because they put the spiritual life in the first and they will not be bothered by the material things. They enjoy more spiritual life such as religious life and art life. On the contrary, the white worship the material and their life is a process of constantly asking for material things from the nature and changing the nature at their will. Instead of going back to the aboriginal life style, the white should learn some useful ways of treating the nature properly from the Aborigines.

\section{References}

Brewster, A. (2011). Whiteness and Indigenous Sovereignty in Kim Scott's That Deadman Dance. The Journal of the European Association of Studies on Australia, 2(2).

Glotfelty, C., \& Fromm, H. (Eds.). (1996). The Eco-criticism Reader; Landmark in Literary Ecology. Athens: The University of Georgin Press.

Scott, K. (2007). Covered up with sand. Meanjin, 66(2). Melbourne: Meanjin Press.

Scott, K. (2011). That Deadman Dance. Sydney: Picador by Pan Macmillan Australia Pty Limited.

Lu, S. Y. (2000). Ecological Research in Literature and Art. X'an: Shaanxi People's Education Press.

Lu, S. Y. (2006). The Space for Eco-criticism. Shanghai: East China Normal University Press.

\section{Copyrights}

Copyright for this article is retained by the author(s), with first publication rights granted to the journal.

This is an open-access article distributed under the terms and conditions of the Creative Commons Attribution license (http://creativecommons.org/licenses/by/3.0/). 